\title{
Climatic Hazards and Impacts on Agricultural Practices in Southern Part of Bangladesh
}

\author{
Md. Saifur Rahman", A. K. M. Abdul Ahad Biswas, Shahriar Rahman, Md. Tauhidul Islam, \\ A. K. M. Mostafa Zaman, Md. Nurul Amin, Md. Shamsuzzoha, Md. Shahin, Md. Abdur Rahim, \\ Md. Touhiduzzaman
}

Faculty of Disaster Management, Patuakhali Science and Technology University, Dumki, Patuakhali, Bangladesh

\section{Email address:}

sfr_rahman@yahoo.com (M. S. Rahman), aahadpstu@yahoo.com (A. K. M. A. A. Biswas), rahman.shahriar@mail.com (S. Rahman), tauhidferdows@gmail.com (M. T. Islam), mostafazamanpstu@gmail.com (A. K. M. M. Zaman), namines@pstu.ac.bd (M. N. Amin), zohageo@gmail.com (M. Shamsuzzoha), shahin.ruet@yahoo.com (M. Shahin), arahim@pstu.ac.bd (M. A. Rahim), touhidgeo@pstu.ac.bd (M. Touhiduzzaman)

\section{To cite this article:}

Md. Saifur Rahman, A. K. M. Abdul Ahad Biswas, Shahriar Rahman, Md. Tauhidul Islam, A. K. M. Mostafa Zaman, Md. Nurul Amin, Md. Shamsuzzoha, Md. Shahin, Md. Abdur Rahim, Md. Touhiduzzaman. Climatic Hazards and Impacts on Agricultural Practices in Southern Part of Bangladesh. Journal of Health and Environmental Research. Vol. 1, No. 1, 2015, pp. 1-11. doi: 10.11648/j.jher.20150101.11

\begin{abstract}
Global climate change is growing threat to lives and livelihoods on earth where the developing countries are highly exposed to climatic variations. Due to a unique geographical location Bangladesh is one of the worst affected countries by climate induced hazards. Coastal region of the country experiences numerous adverse pressures resulting from these natural phenomenon. Long term changes in climatic parameters such as temperature, rainfall, humidity creates extra pressure of climate change impact. Agriculture of coastal area is one of the most vulnerable sectors to climatic hazards. The current study was conducted to assess the major climatic hazards and impacts on cropping pattern at Kalapara Upazila of Patuakhali District of Bangladesh. The study was designed mainly to identify the latest sustainable change gradually adopted by local farmers in their cropping pattern as the coping strategy. Methodology followed was the consideration of farmers' perception and field based data collection including Questionnaire Survey, Focus Group Discussion and personal observation. Major climatic hazards including sea level rise, salinity intrusion, cyclone with storm surge, tidal surge, coastal inundation, erratic rainfall and riverbank erosion were found predominant in the study area. However farmers identified salinity intrusion, cyclone, storm surge, tidal surge and erratic rainfall as most common and severe constrains to crop production practices. Previously practiced cropping pattern and season has been changed responding towards climatic variations. Cultivation of some crops has been increased while some other has been decreased. Some varieties of crops including jute, sesame, and sugarcane are going to be extinct because of salinization. Farmers need technical and logistic support to minimize the impact of climatic hazards impact to protect the loss of crop production. Dissemination of salinity tolerant varieties, some structural and non-structural mitigation and adaptation measures can be the part of most suitable risk reduction action plan to reduce the climate change vulnerability in crop agriculture.
\end{abstract}

Keywords: Climatic Hazards, Cropping Pattern, Farmers’ Perception

\section{Introduction}

Climate change is a burning issue from the last century and still continuous threat to lives on earth. Numerous hazards with increasing intensity and frequency are originated from climatic variations. Bangladesh is one of the most vulnerable countries to climate change in the world and will become even more susceptible in the future (Islam M. A., 2011). Climate induced hazards like floods, cyclones, storm surges and droughts are expected to become more frequent and severe in the near future. Climate change has already impacted the life and livelihood of people in the coastal areas and in the arid and semi-arid regions of Bangladesh (MOP, 2011).

Though land are fertile and can produce a lot of crop production that contribute in food security; agricultural crop production damage frequently due to unexpected climatic hazard. Bangladesh observes severe exposure to such risks because of its geo-morphological, demographic and socio-economic character (Agrawala et al., 2003). Agricultural sector will be remarkably affected due to climate change impacts resulting different climatic Hazards/ Disasters is mentioned in National Adaptation Program of Action 
(NAPA, 2010). Climate change has tremendous negative effect on agriculture and food security; the total productions will loss in greater rate (Yusuf et al., 2009).Crop agriculture is probably the mostly vulnerable sector due to climate change.

\subsection{Background of the Study}

Climate change is a significant and long-term change in the statistical distribution of weather patterns over periods of time that range from decades to millions of years. It may be a change in the average weather conditions or a change in the distribution of weather events with respect to an average, for example, greater or fewer extreme weather events. Climate change may be limited to a specific region, or may occur across the whole Earth (IPCC 2007).

Humid and subtropical countries would be more exposed to the impending impacts of global warming. It is supposed that climate variation would upsurge the disparities in cereal production among advanced and third world countries. The production in the advanced world would profit from climate change, while that in developing country would drop (Briefing et al. 2009).

IPCC report predicts that in South Asia, monsoon precipitation will be increased, resultant in higher tides during rainy season in the river system. It is also predicted that sea level will rise between 0.18 to 0.79 meters that will lead to saline water intrusion and tidal flooding (Ahmed and Suphachalasai, 2009).

Rahman (2008) commented different general effects of climate change like increasing mean, minimum and maximum temperatures; ongoing fluctuations in precipitation; upsurge in the frequency, extent and strength of dry influences and droughts; variations in the timing, longevity, intensity and topographical position of rain snowfall, rise in the occurrence and strength of storms and floods. Bangladesh is more likely exposed countries facing the negative impacts of climate change. The country lies between $20^{\circ} 34^{\prime}$ to $26^{\circ} 38^{\prime}$ North latitude and $88^{\circ} 01^{\prime}$ to $94^{\circ} 45^{\prime}$ East longitude. As it has a unique geographic location, control of floodplains and coastal topography, high population density, high levels of poverty, and highly dependence on natural assets and facilities, several of which is climate sensitive (Avhandling 1981).

Base line study found that Kalapara is one of the worst affected Upazila of Patuakhali District of Bangladesh by numerous climatic disasters. Among them salinity intrusion, consequent cyclone and storm surge, erratic rainfall are highly influenced on crop production. This study is designed to find out the existing climatic hazards with their extent and influence on crop sector. Changes in cropping pattern and cropping season will also be focused.

\subsection{Objectives of the Study}

The study was designed considering some specific objectives which are as follows-

1. To study the impact of climate change influences on crop agriculture.

2. To investigate farmers' perception towards climatic hazards.

3. To determine the changes in cropping seasons and pattern considering the past.

\section{Methodology}

\subsection{Selection of the Study Area}

Kalapara is an Upazila of Patuakhali District which is one of the worst affected Upazila by salinization, recurrent storm-cyclone and storm surge and many other climatic hazards events and especially the farmer's main livelihoodagriculture is seriously affected. Among the nine unions three-Nilganj, Chakamiya and Tiakhali were selected for the current research.

\subsection{Primary Data Collection}

To estimate the existing hazards with their severity and influence on agriculture, the respondents were asked the common questions. The study was designed according to the farmers' perception where sample size was small. Here the average data were used which may reduce robustness of the study. The study was designed preferring qualitative description rather than quantitative data. However, data were rechecked and compared with established literature to maintain the rigor of the study. Primary data were collected through various methods such as-

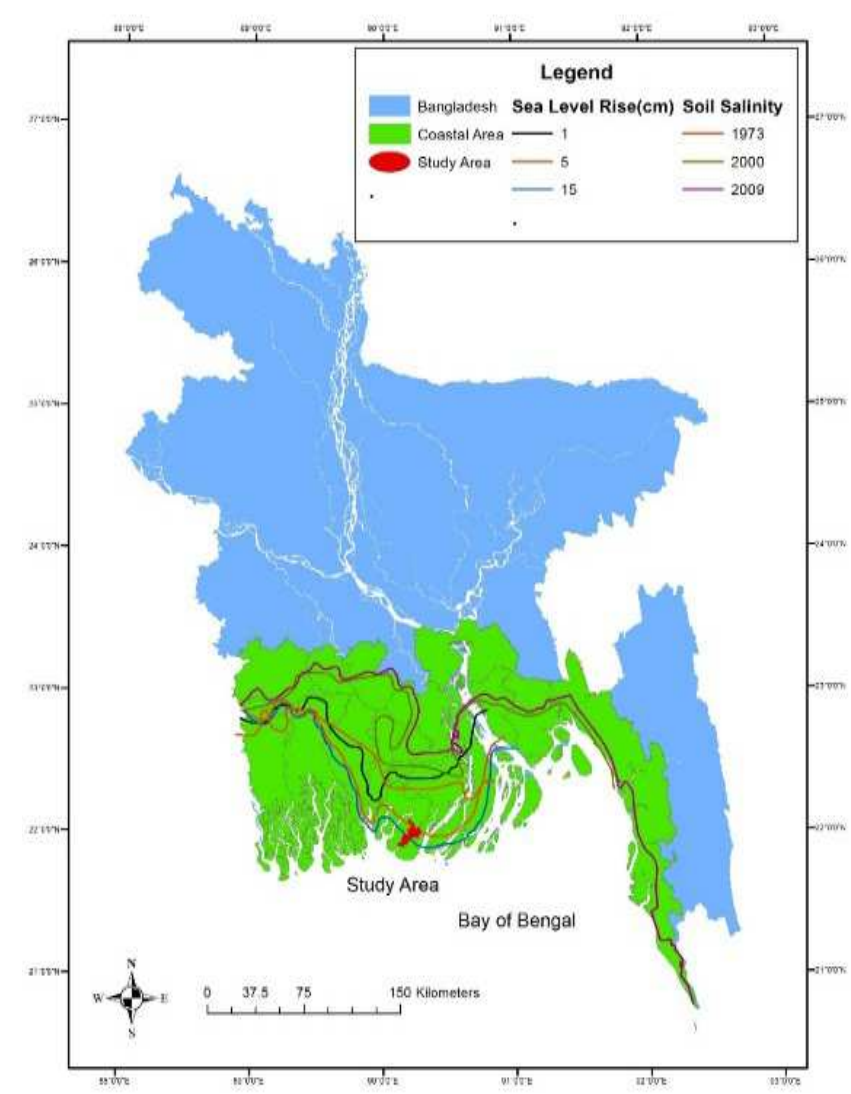

Figure 1. Map Indicating Physiography of the Study Area (Data Source: CEGIS, 2014). 


\subsubsection{Questionnaire Survey}

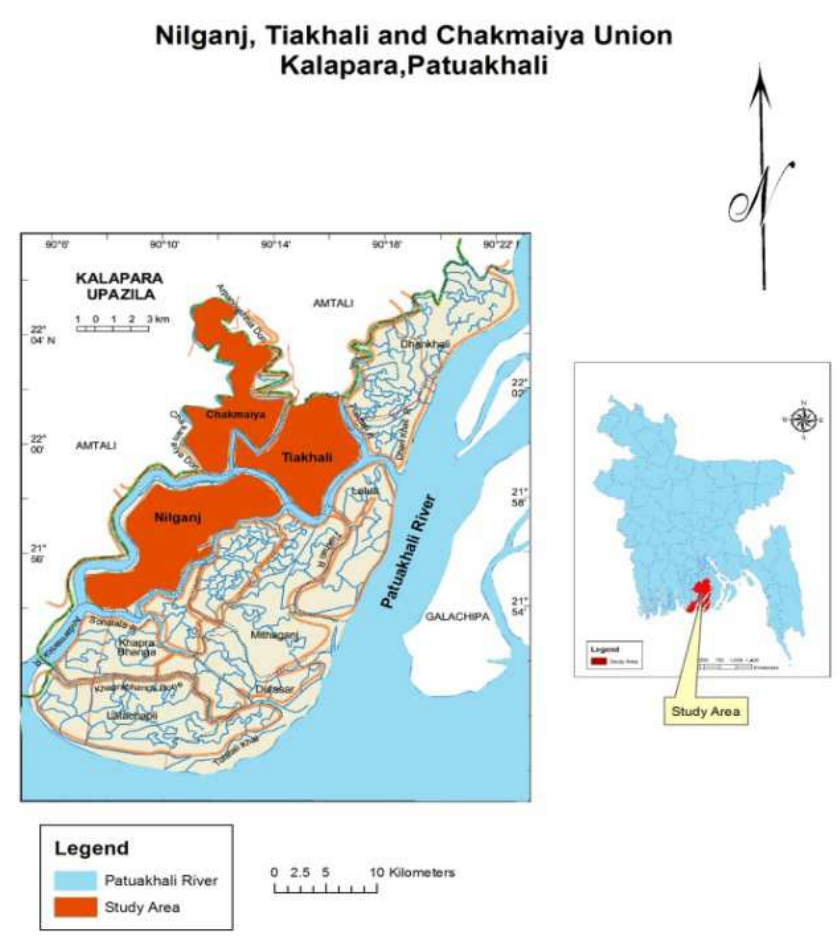

Figure 2. Map showing the Study Area.

Data were collected through observations, Questionnaire Survey (QS) and transect walking. Firstly, the farmers of selected unions who are directly involved in agriculture were selected. According to the schedule $(20 \times 3)=60$ interviews were taken following questionnaire to collect the information from three selected unions. The selected farmers were of mixed of all categories such as marginal, medium and rich farmer.

During data collection the following key queries problems were highly focused-

- Existing climatic hazards and main disasters farmers face and their impact on local agriculture

- Existing practices and further measures to be taken reducing the impact of climate change and enhancing the sustainable production

\subsubsection{Focus Group Discussion (FGD)}

FGD was designed to make-Hazard Calendar to identify the probability of occurring of hazards at different cropping time of the year; Crop Calendar is to identify the susceptibility of crops due to impact of different climatic disasters and to study the regional existing change in cropping pattern considering the previous practices.

\subsection{Secondary Data Collection}

The information has been collected from different relevant scientific articles, reports, maps, journals, research paper, website, library, Kalapara Upazila Agriculture Office and some local NGO offices etc. The information about the local crop cultivation practices; change in past and present cropping pattern related issues was gathered by cross matching among different sources.

\subsection{Data Analysis}

After the survey gathered date from completely filled up questionnaires, FGD, secondary information's were processed and analyzed using Microsoft Excel computer software to make graphical representation and interpretations.

\section{Result and Discussion}

\subsection{Overall Analysis of Geo-physical Condition}

\subsubsection{Geography}

Kalapara Upazila of is the area of $483.08 \mathrm{sq} \mathrm{km}$, located in between $21^{\circ} 48^{\prime}$ and $22^{\circ} 05^{\prime}$ north latitudes and in between $90^{\circ} 05^{\prime}$ and $90^{\circ} 20^{\prime}$ east longitudes. It is bounded by Amtali Upazila on the north, Bay of Bengal on the south, Rabnabad Channel and Galachipa Upazila on the east, Amtali Upazila on the west (Banglapedia, 2003).

\subsubsection{Physiography}

The physiography is shown in Figure 1and the location of the study area is shown in Figure 2.

In Figure 1 it is shown that Kalapara is an Upazila of Patuakhali District which is situated at the coastal zone of Bangladesh. According to CEGIS data the area is also affected by salinity, sea level rise, cyclone and storm surge (Figure 1). The selected unions (Nilganj, Tiakhali and Chakamiya) are marked with red color in the map which is the worst affected unions by different climatic factors (Figure 2).

\subsubsection{Demography}

Selected unions have different demographic characteristics which are given in Table 1.

Table 1. Number of Household, Population in the Study Area (Source: BBS, 2011).

\begin{tabular}{llll}
\hline $\begin{array}{l}\text { Administrative Name } \\
\text { of the Union }\end{array}$ & $\begin{array}{l}\text { Area in } \\
\text { Acres }\end{array}$ & Total HH & Total Population \\
\hline Tiakhali & 8126 & 3565 & 14342 \\
Chakamaiya & 8496 & 4974 & 16472 \\
Nilganj & 15648 & 7282 & 29019 \\
\hline \multicolumn{4}{l}{} \\
\hline In HH & Floating & Population density sq.km \\
14301 & 41 & 436 & \\
16472 & 0 & 479 & \\
29019 & 0 & 458 & \\
\hline
\end{tabular}

\subsubsection{Socio-economic Condition}

In Figure 3 it is found that main sources of income in the study area is agriculture (Crop, Fisheries and Livestock, Agriculture wage laborer) 57.23\%,non-agricultural laborer $4.80 \%$, industry $0.43 \%$, commerce $13.50 \%$, transport and communication $2.14 \%$, service $4.56 \%$, construction $1.36 \%$, religious service $0.21 \%$,rent and remittance $0.20 \%$ and others $15.57 \%$ (BBS, 2011). 


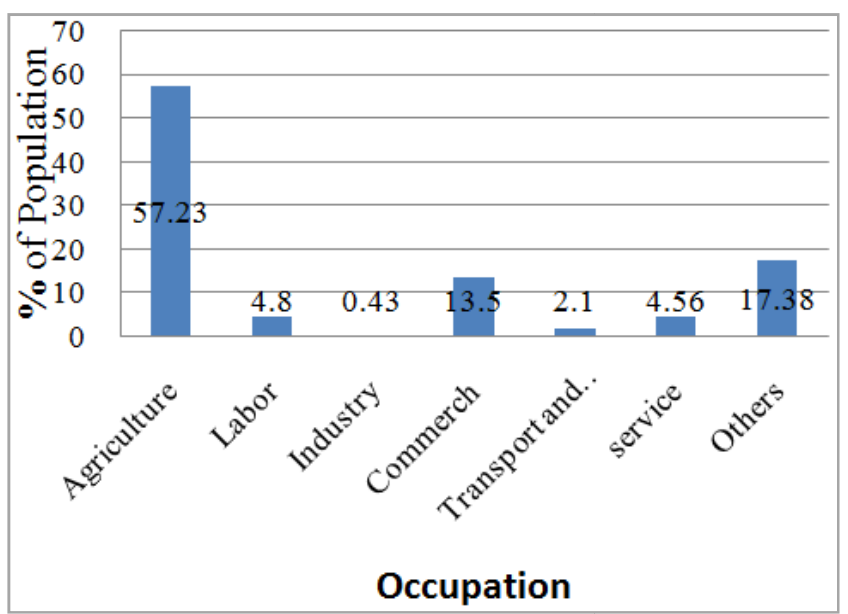

Figure 3. Occupation of People (\%) (Data Source: BBS 2011).

\subsection{Climatic Hazard's Impact Analysis}

Crop agriculture is highly influenced by climatic hazards and farmers are the direct victims. So in this study it was tried to identify the adverse climatic factors which they are facing as constrains to crop production and to focus on the major climatic hazards which they have faced to crop production. So that development organizations can emphasize on the right one for further Disaster Risk Reduction (DRR) and Climate Change Adaption (CCA) practices.

\subsubsection{Impact of Climate Change on the Study Area}

From the QS, FGD personal experience and observation and data collected from government Agriculture Extension Office (AEO) it was tried to find the adverse impact of climate change on agriculture for Nilganj, Tiakhali and Chakamiya unions of Kalapara Upazila. Crop cultivation is negatively influenced by temperature fluctuations, erratic rainfall, soil and water salinity, drought, floods, river erosion, tropical cyclones and storms. All of those are likely to rise as a consequence of climate change.

\subsubsection{Sea Level Rise and Salinity Intrusion}

Data analysis revealed that when the downstream flow of fresh water becomes very low during the latter part of the dry (winter) season, the salts enter inland through rivers and channels, especially during this period, the salinity of the river water surges. By flooding the salts enter the soil with salt containing river water or by seepage from the rivers, and the salts become contaminated in the surface layers due to evaporation. The increase in water salinity of these areas has created suitable habitat for shrimp cultivation. Along with other factors, shrimp cultivation played a major role to increase salinity in Nilganj, Chakamiya and Tiakhali. Figure 4 showed that the Rabi crops and Boro rice are mostly affected by salinity because during dry season the salinity rises at a higher rate.

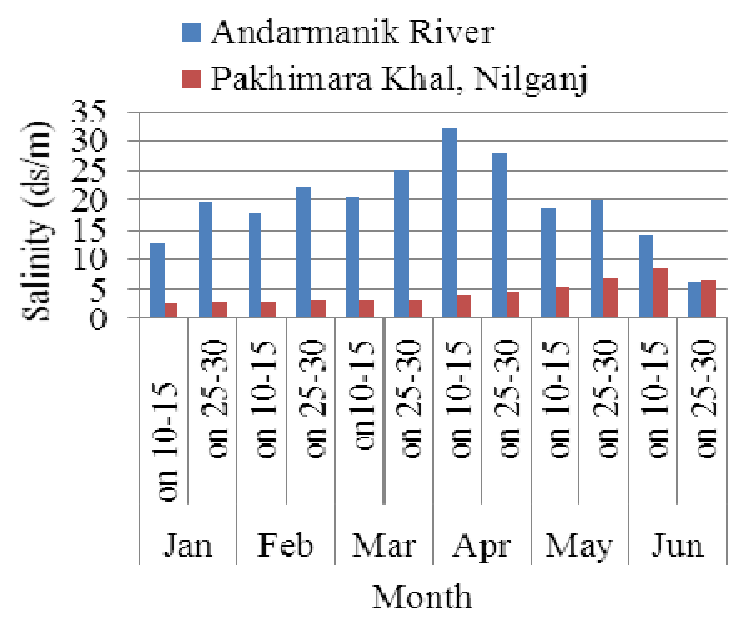

Figure 4. Salinity condition of the study area.

Figure 4 indicates that salinity extent is higher in hot dry season because of lack of rainfall e.g. explained in erratic rainfall and higher rate of evaporation concentrating salt in the water and soil. Rabi crops and Boro rice are mostly affected by salinity problem-affects plant growth and reduce yield of crops. Salinity decreases with the increase of rainfall. It is observed that salinity and associated water logging damage infrastructure like embankment, polder etc. and results in reducing water quality and soil fertility.

\subsubsection{Impact on Crop Agriculture Due to Increasing of Frequency and Intensity of Tropical Cyclones}

Cyclone cause huge damage to production of crop. Bangladesh had experienced two devastating cyclone named "SIDR" and "AILA" in 2007 and 2009 respectively causing a wide spread damage on crop sector in the country (AEO, 2010). Data analysis shows that current study area also experienced huge damage of crops. During cyclone SIDR, Aman rice crops were fully damaged about $45 \%$ and almost damaged $40 \%$ (Figure 5) and during cyclone AILA, Aman rice crops were fully damaged about $40 \%$ and almost damaged $40 \%$ (Figure 6). From the figures 5 and 6 , it is clear that recurring cyclone phenomena has a significant influence on damaging crops.

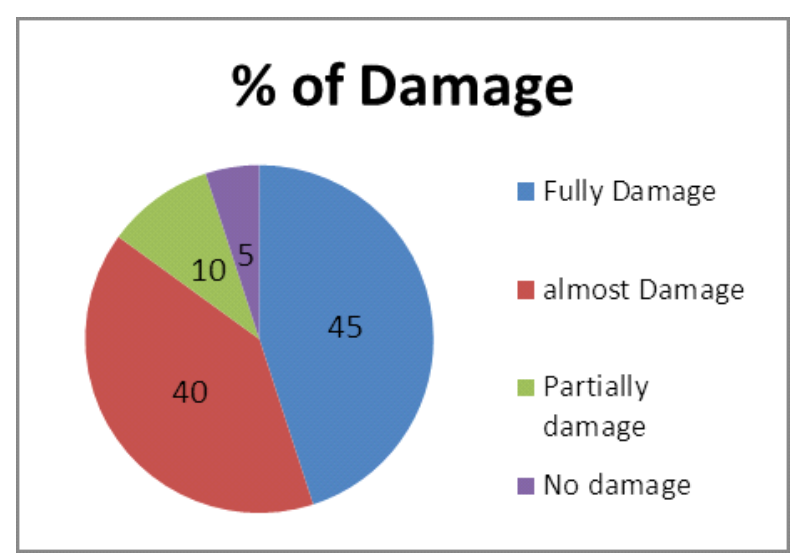

Figure 5. Percentage of Crop Damage Due to "SIDR" (Data Source: AEO, 2010). 


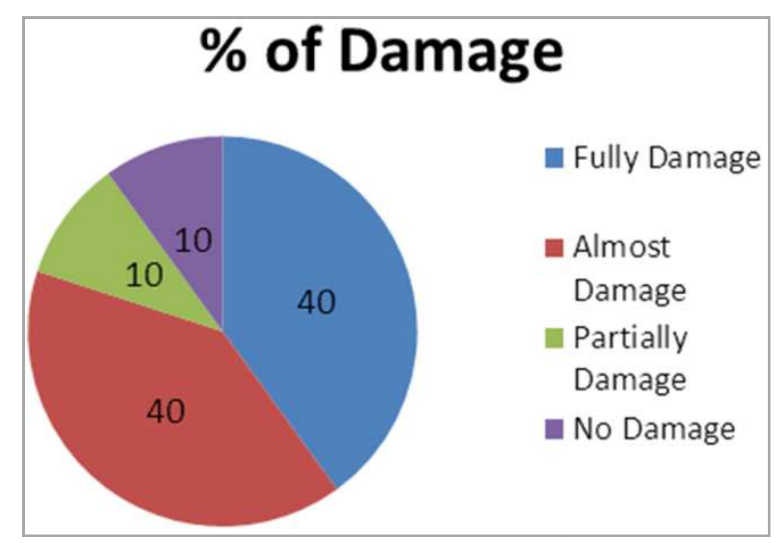

Figure 6. Percentage of Crop Damage Due to "AILA" (Data Source: AEO, 2010).

From the figure 7 it is observed that risk of occurring cyclone is high in April to May (Pre monsoon), and October to November (Post Monsoon). Local farmers cultivate Pulse, T-Aus, T-Aman and some minor vegetables during pre and post monsoon and these crops are highly vulnerable to cyclone and storm surge. From the analysis it is observed that due to tropical cyclone the cereal crop production is reduced. Storm surge and saline water intrusion results in damages of polders and embankments and long term water logging in these areas hinders the growth of crop yield.

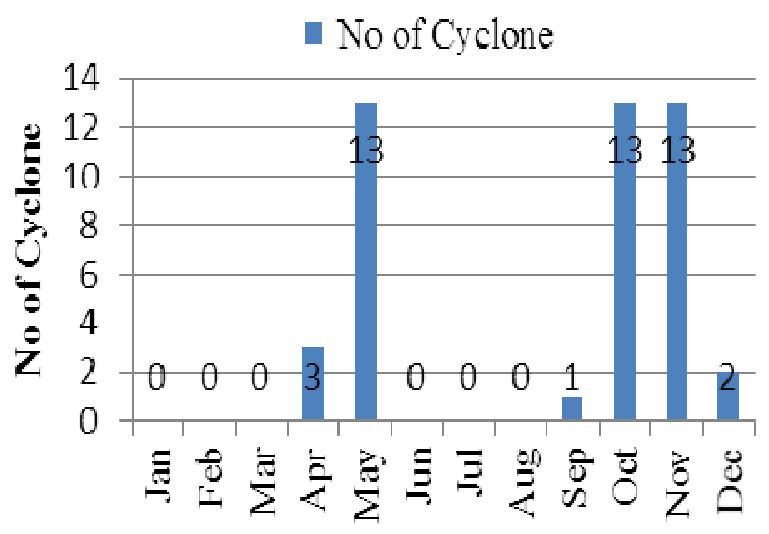

\section{Month}

Figure 7. Monthly Distribution of 45 major Cyclone During 1797-2007(BUET, 2008).

\subsubsection{Ingression of Soil Salinity}

Soil salinity may rise as a result of saline water intrusion, especially during the time of irrigation with slightly saline surface water are entered at the starting of the low flow period. Data collected from Kalapara Agriculture Office has shown that salinity ranged between 8 to $12 \mathrm{ds} / \mathrm{m}$ during the low flow season (AEO, 2010).

Unfortunately distribution in rainfall pattern is unusual and uneven at recent years as a result of climate change. This unusual trend in rainfall distribution leads lack of rain at dry season and excessive rain in monsoon period.

\subsubsection{Erratic Rainfall}

Rainfall is one of the major climatic factors that have a strong influence on crop production. Most of the crops have critical stage when needs sufficient amount of rain. At growth stage of plant excessive rainfall may cause water logging and monsoon flood leads to crop damage.

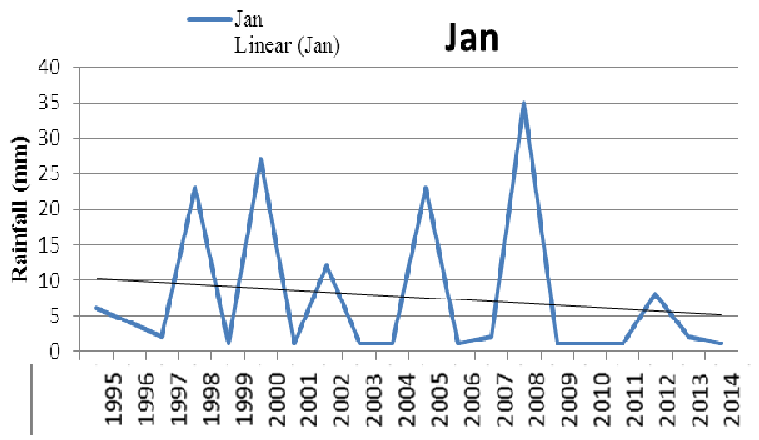

Figure 8. Rainfall Trend Line of January in Last 20 years (1995-2014) (Data Source: BMD, 2015).

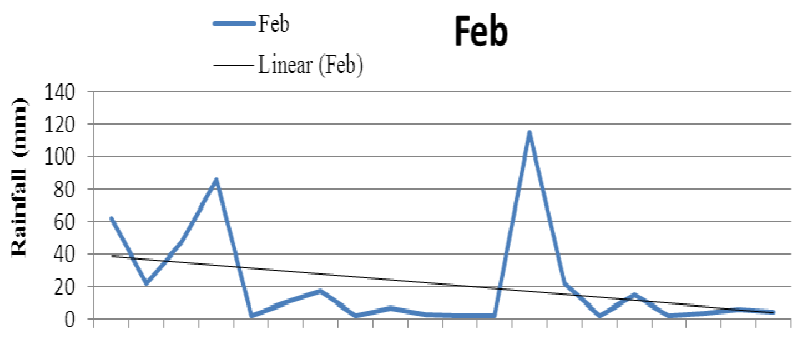

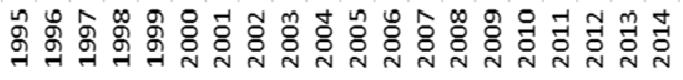

Figure 9. Monthly Rainfall Trend Line of February in Last 20 years (1995-2014) (Data Source: BMD, 2015.

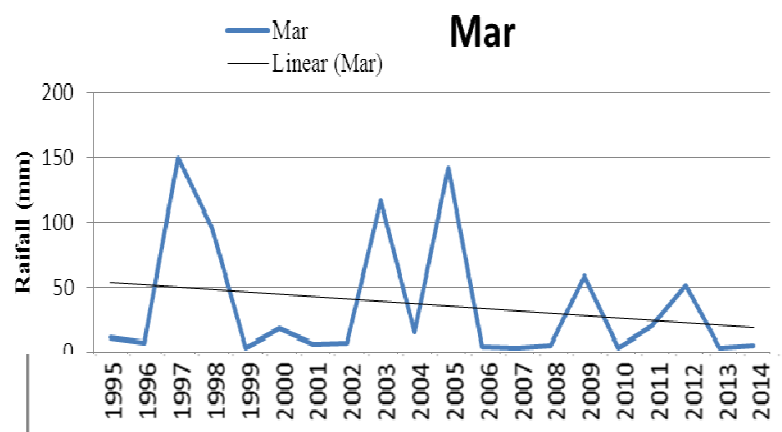

Figure 10. Monthly Rainfall Trend Line of March in Last 20 years (1995-2014) (Data Source: BMD, 2015.

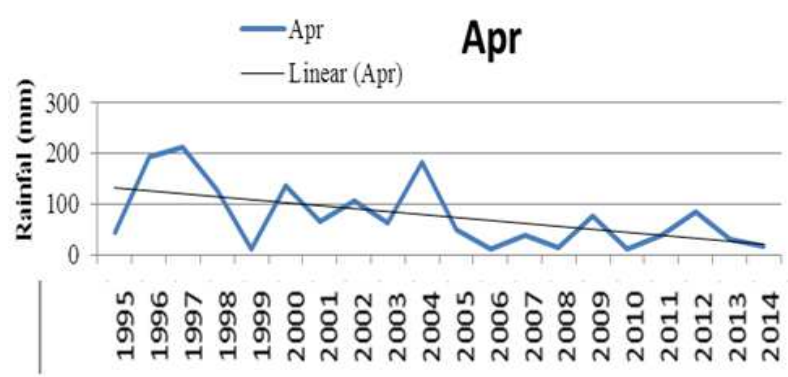

Figure 11. Monthly Rainfall Trend Line of April in Last 20 years (1995-2014) (Data Source: BMD, 2015. 


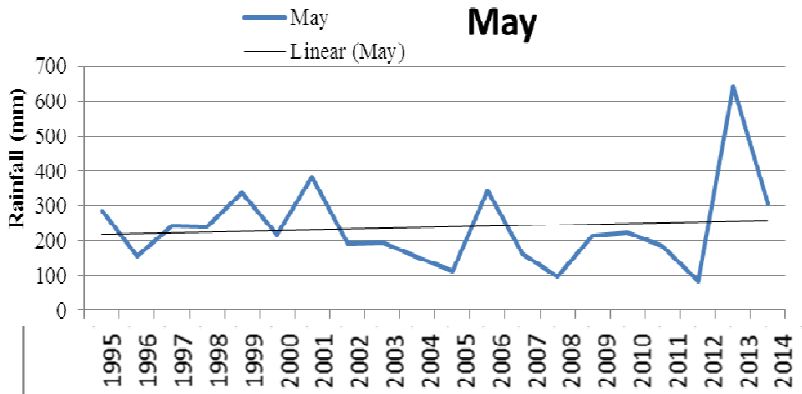

Figure 12. Monthly Rainfall Trend Line of May in Last 20 years (1995-2014) (Data Source: BMD, 2015).

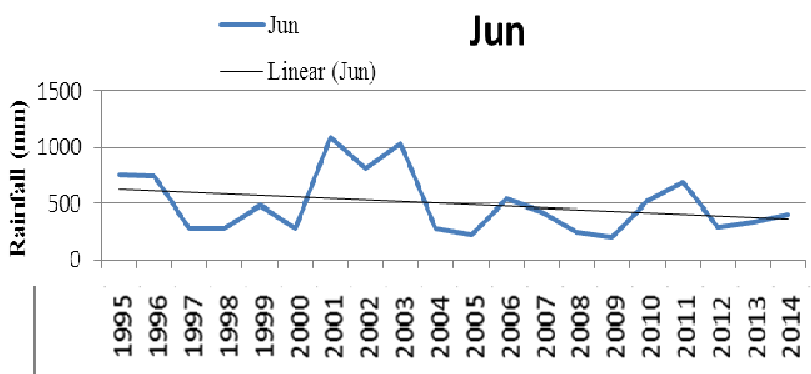

Figure 13. Monthly Rainfall Trend Line of June in Last 20 years (1995-2014) (Data Source: BMD, 2015).

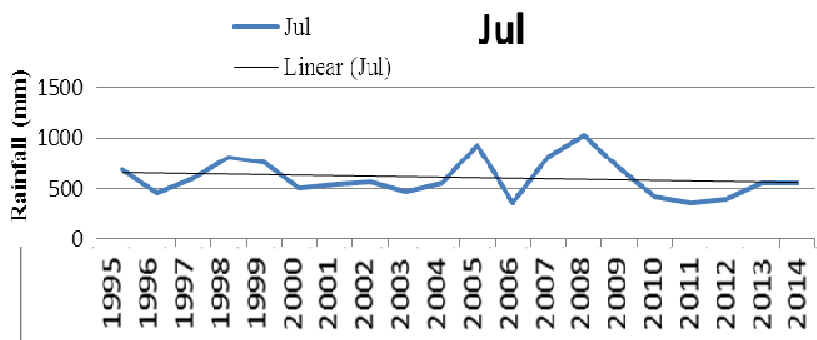

Figure 14. Monthly Rainfall Trend Line of July in Last 20 years (1995-2014) (Data Source: BMD, 2015).

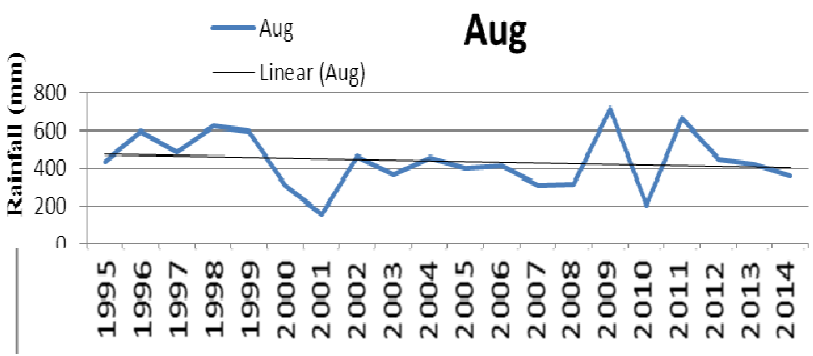

Figure 15. Monthly Rainfall Trend Line of August in Last 20 years (1995-2014) (Data Source: BMD, 2015).

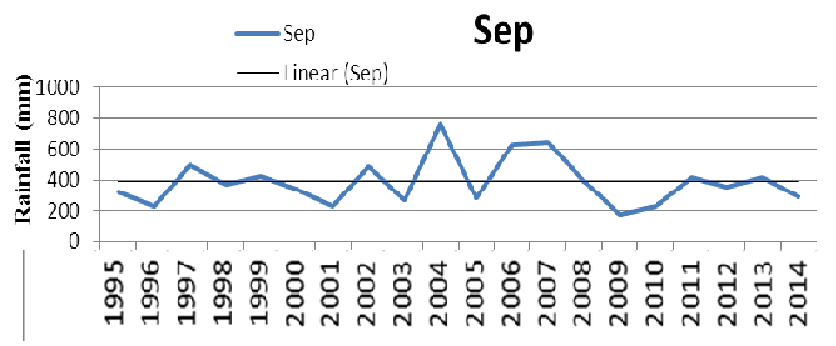

Figure 16. Monthly Rainfall Trend Line of September in Last 20 years (1995-2014) (Data Source: BMD, 2015).

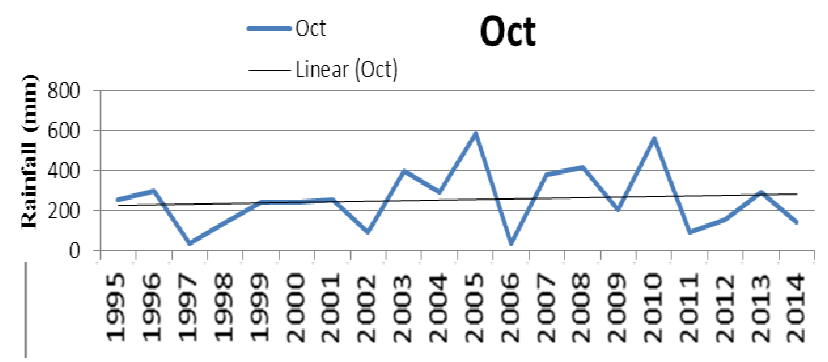

Figure 17. Monthly Rainfall Trend Line of October in Last 20 years (1995-2014) (Data Source: BMD, 2015).

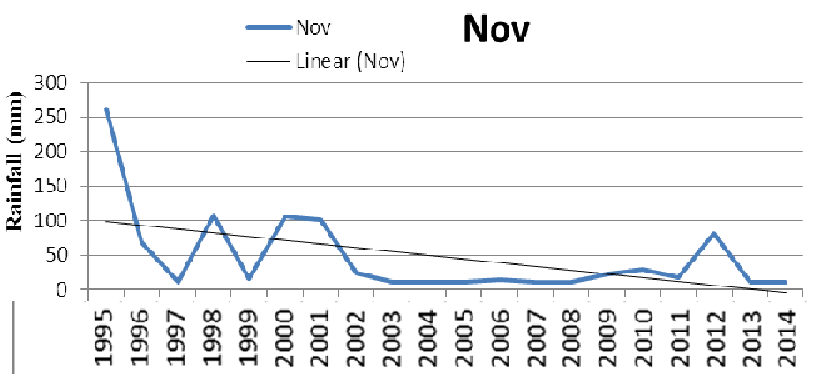

Figure 18. Monthly Rainfall Trend Line of November in Last 20 years (1995-2014) (Data Source: BMD, 2015).

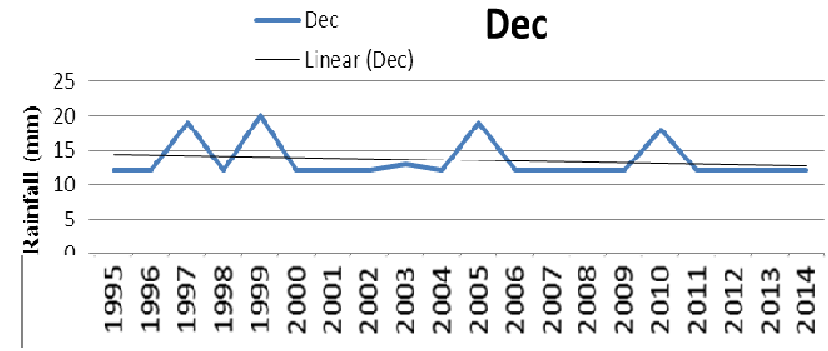

Figure 19. Monthly Rainfall Trend Line of December in Last 20 years (1995-2014) (Data Source: BMD, 2015)

Monthly rainfall distribution from 1995 to 2014, it is observed that decreasing trend line is shown in November to April (Figure 18, 19, 8 to 11) and June to August (Figure 13 to 15). Whereas increasing trend line is shown in May and October (Figure 12 and 17) and flat trend line is shown in September (Figure 16).It is shown that less amount of rainfall which is almost $05-50 \mathrm{~mm}$ from December to March (Figure 19,8 to 10), medium amount of rainfall which is almost 200-300 mm in May and October (Figure 12 and 17), and high amount of rainfall which is almost 400-600 $\mathrm{mm}$ from June to September (Figure 13 to 16). In April almost 25-150 mm (Figure 11) and in November almost 0-100 mm (Figure 18) rainfall is observed. So it is noted that the amount of rainfall is less in winter and dry summer season and the trend is decreased consequently in monsoon season the amount of rainfall is high. Increasing trend line is found in May and October. So fluctuation of rainfall distribution is observed all over the year which has an adverse impact on crop agriculture.

It is also observed that cultivation of Aus and Aman rice is hindered by variability of rainfall, uncertain date of onset. Uncertain rainfall results delay sowing and transplanting of Aus and Aman rice. Heavy monsoon rainfall leads delay in 
transplanting Aman rice many times. Late rainfall at the end of the rainy season causes great harm of vegetables in Rabi season. The farmers cannot cultivate vegetables in due time because of rain water in their cropland due to excessive rainfall. Variability in wetness of soil due to erratic rainfall, and therefore the sowing time of the crops, is also affected.

\subsubsection{Tidal Surge and Coastal Inundation}

As a result of climate change, sea level rise, excessive rainfall during the monsoon and post monsoon season there prevail high tide in sea and river. Study revealed that high amount of tidal water sometimes causes tidal surge and coastal inundation almost every year causing serious damage to crop agriculture in the study area. It is also observed that crops are submerged by tide and root zone becomes weaker leads slower growth or partial damage. Crops also floated away by tide water cause full or partial damage.

\subsubsection{Storm, Hail Storm and Thunder Storm}

From the Questionnaire Survey it is observed that the study area experiences one or two storms in each year and a very severe storm shows in every 3 years. Occurrence of hail storm is also increasing as a result of climate change and in every three or four year this area experiences significant hail storm. Thunder storm occurs twice or thrice in every year in this area. A severe storm cause moderate to high damage to cereal crops with wind speed. Severe hail storm can cause huge damage to crops and thunder storm causes partial damage.

\subsubsection{Riverbank Erosion}

Due to excessive rainfall and tidal surge the riverbank is eroded. From field survey it was found that due to river bank erosion loss of cultivable land and land degradation cause yield reduction.

\subsection{Farmer's Perception towards Climatic Hazards}

To determine the extent and severity of climatic hazards through field survey farmers' perception was explored that it hindrance to crop production.

\subsubsection{Seasonal Hazard Calendar}

According to farmer's experience of occurring adverse impact of climate change at different time extent a seasonal hazard calendar was prepared for each of Nilganj, Tiakhali and Chakamiya union.

The codes of each calendar such as very high [5], high [4], moderate [3], low [2], very low [1] and no risk [0] are used for understanding the risk or probability of occurrence of particular hazards at different time of the year.

Tables 2, 3, 4 show that salinity, cyclone with storm surge and tidal surge are the mostly adverse climatic hazards in the study area according to farmers' perception.

It is found that salinity problem remains high in dry hot season and reaches peak position in March at Nilganj and Chakamiya and in April-May at Tiakhali which affects mostly Boro rice and Rabi crops. Risk of cyclone and storm surge remains high in pre monsoon (April-May) which affect T. Aus and in post monsoon (September-November) causing a huge damage to T. Aman rice. Tidal surge found is moderate risk during monsoon which affects Aman rice. Wind storm occurs during March-May whereas erratic rainfall affects crop production at different time of the year. Pest attack is up surged by different climatic factors like extreme temperature and erratic rainfall and affects crops highly pre-monsoon (April-May) and post monsoon (September-October).

Table 2. Seasonal Hazard Calendar of Nilganj.

\begin{tabular}{|c|c|c|c|c|c|c|c|c|c|c|c|c|}
\hline Very High & 4 & High & 3 & Mo & & 2 & Low & 1 & Very Low & $\mathbf{0}$ & No & \\
\hline Hazard/Month & Jan & Feb & Mar & Apr & May & Jun & Jul & Aug & Sep & Oct & Nov & Dec \\
\hline Cyclone and Storm Surge & 0 & & 1 & 4 & & 2 & 0 & & 3 & 4 & & 0 \\
\hline Wind Storm & 0 & 1 & 3 & & 4 & 1 & 0 & 1 & & 0 & & \\
\hline Excessive Rainfall & 0 & & & & & 2 & 3 & 2 & 1 & & 0 & \\
\hline Lack of Rainfall & 0 & 2 & 3 & & 2 & 0 & & & 1 & & 0 & \\
\hline Tidal Surge & 0 & & & 1 & & 3 & & 2 & 0 & & & \\
\hline Thunder Storm & 0 & & 2 & 4 & 3 & 1 & 0 & & 1 & 0 & & \\
\hline Hail Storm & 0 & & 1 & 2 & & 0 & & & & & & \\
\hline Pest Attack & 1 & & 2 & 3 & & 0 & & 2 & 3 & & 1 & \\
\hline Water Logging & 0 & & & & 1 & & 2 & & 1 & & & 0 \\
\hline Riverbank Erosion & & o & 1 & & & 2 & & 1 & & 0 & & \\
\hline
\end{tabular}

Table 3. Seasonal Hazard Calendar of Chakamiya.

\begin{tabular}{|c|c|c|c|c|c|c|c|c|c|c|c|c|}
\hline Hazard/Month & Jan & Feb & Mar & Apr & May & Jun & Jul & Aug & Sep & Oct & Nov & Dec \\
\hline Salinity & 1 & 2 & 4 & 2 & & 1 & 0 & & & 0 & & \\
\hline Cyclone and Storm Surge & 0 & 0 & 1 & 4 & & 2 & 0 & 1 & 3 & 4 & & 0 \\
\hline Wind Storm & 0 & 1 & 3 & & 4 & 1 & 0 & 1 & & & 0 & \\
\hline Excessive Rainfall & 0 & & & & & 2 & 4 & 3 & 1 & & 0 & \\
\hline Lack of Rainfall & 0 & 1 & 2 & 3 & 2 & 0 & & & 1 & & 0 & \\
\hline Tidal Surge & 0 & & & 1 & 2 & 3 & 4 & 2 & 1 & 0 & & \\
\hline Thunder Storm & 0 & & 2 & 4 & 3 & 1 & 0 & & 1 & 0 & & \\
\hline
\end{tabular}




\begin{tabular}{|c|c|c|c|c|c|c|c|c|c|c|c|c|}
\hline Hazard/Month & Jan & Feb & Mar & Apr & May & Jun & Jul & Aug & Sep & Oct & Nov & Dec \\
\hline Hail Storm & 0 & & 1 & 2 & 2 & 0 & & & & & & \\
\hline Pest Attack & 1 & & 2 & 3 & & 0 & & 2 & 3 & & 1 & \\
\hline Water Logging & 0 & & & & 1 & 2 & 3 & & 1 & 2 & 1 & 0 \\
\hline Riverbank Erosion & 0 & o & 1 & & & 2 & & 1 & & 0 & & \\
\hline
\end{tabular}

Table 4. Seasonal Hazard Calendar of Tiakhali.

\begin{tabular}{|c|c|c|c|c|c|c|c|c|c|c|c|c|}
\hline Hazard/Month & Jan & Feb & Mar & Apr & May & Jun & Jul & Aug & Sep & Oct & Nov & Dec \\
\hline Salinity & 1 & & 2 & 4 & & 0 & & & & & & \\
\hline Cyclone and Storm Surge & 0 & & 1 & 4 & & 2 & 0 & & 3 & 4 & & 0 \\
\hline Wind Storm & 0 & 1 & 3 & & 4 & 1 & 0 & 1 & & 0 & & \\
\hline Excessive Rainfall & 0 & & & & & 3 & 4 & 3 & 1 & 0 & & \\
\hline Lack of Rainfall & 0 & 1 & 2 & 3 & & 0 & & & 1 & & 0 & \\
\hline Tidal Surge & 0 & & & 1 & & 2 & 3 & 2 & 1 & 0 & & \\
\hline Thunder Storm & 0 & & 2 & 3 & 2 & 1 & 0 & & 1 & 0 & & \\
\hline Hail Storm & 0 & & 1 & 2 & & 0 & & & & & & \\
\hline Pest Attack & 1 & & 2 & 3 & & 0 & & 2 & 3 & & 1 & \\
\hline Water Logging & 0 & & & & 1 & 2 & & 3 & 1 & 2 & 1 & 0 \\
\hline River Erosion & o & & 1 & & & 2 & & 1 & & 0 & & \\
\hline
\end{tabular}

\subsubsection{Major Climatic Hazards}

While investigating farmers' perception different farmer emphasize on different problem. The percentage of respondent said about different hazards that constrains to crop production which is shown in figure 20 .

From the figure 20 it is clear that salinity, cyclone and storm surge are the most impacted hazards in crop sector by farmers' perception and in an average $65 \%$ respondent consider these as constrains. Erratic rainfall, tidal surge, pest attack are also common in the area.

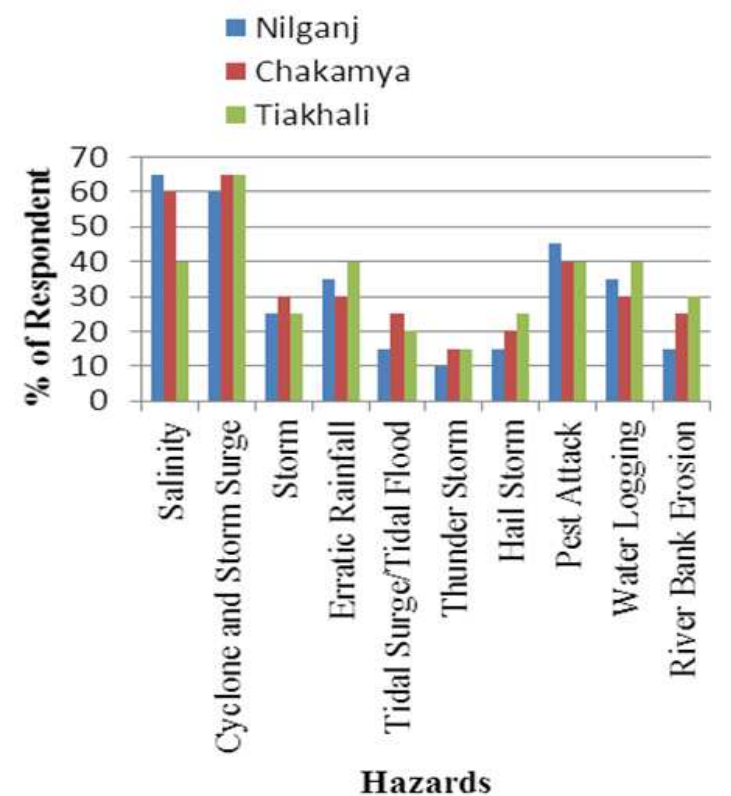

Figure 20. Percentage of Respondent towards Climatic Hazards.

The farmers were also asked about their main climatic constrain to their crop production and the percentage of respondent towards main climatic hazard is shown in figure 21.

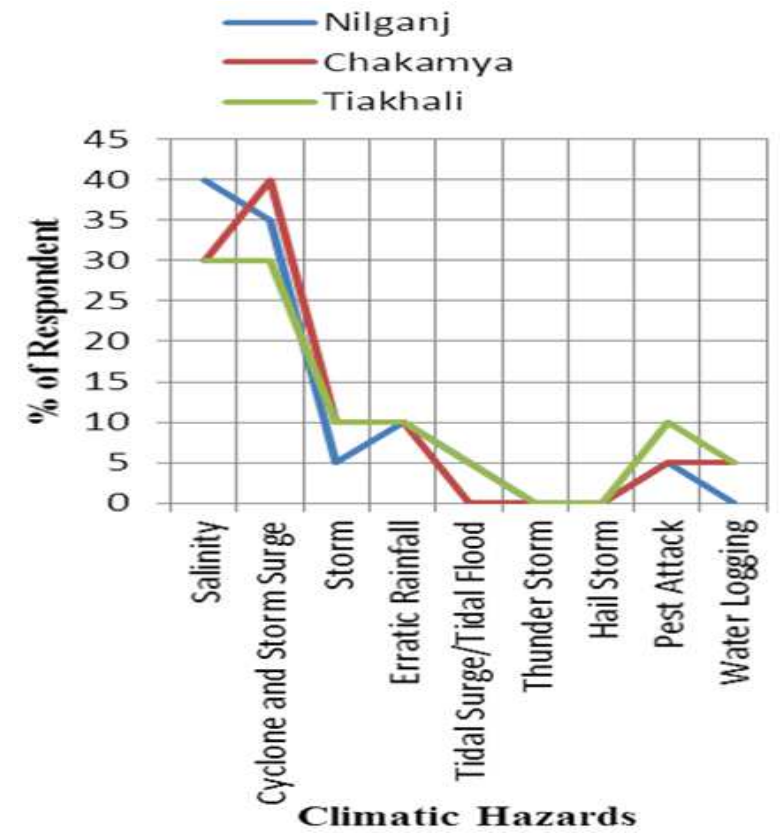

Figure 21. Percentage of Respondent towards Main Climatic Hazard.

Figures 20 and 21 were designed to identify the mostly adverse hazards of climate change on crop agriculture according to farmers' experience because they are the victims. It is quite impossible to mitigate all risk at a short term rather we should emphasize on mitigating the mostly adverse impact that farmer face in their real experience.

Above diagrams indicate that salinity, cyclone with storm surge are the two mostly adverse problems that farmers face for crop production. In average 35\% people emphasize salinity as their main problem while other $35 \%$ think cyclone and storm surge as their main problem because its impact is devastating and straight visual. Pest attack, erratic rainfall, wind storm and tidal surge were also found as main hindrance from $5-10 \%$ respondent. Other hazards have minor response. 


\subsubsection{Climate Driven Environmental Change}

Variability in climatic factors is a common phenomenon as a result of climate change. There are lot of climatic and environmental factors which has been changed during last 15 years. This study has tried to find out those changes from farmers' perception through questionnaire survey and the percentage of respondent towards climatic and environmental changes that are given in the following figure 22.

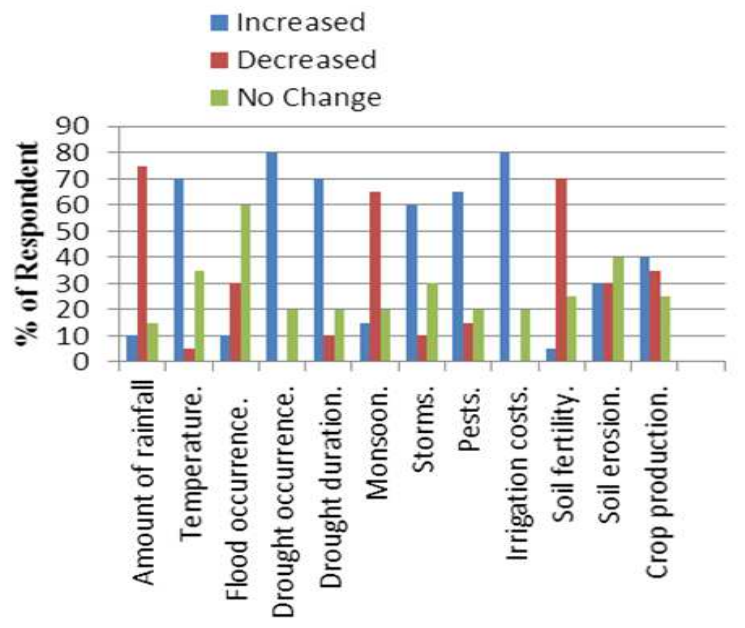

Climate Driven Environmental Issues

Figure 22. Farmers' Perception towards Climate Driven Environmental
Changes in Last 15 Years.

So from the figure 22 it is observed that amount of rainfall, soil fertility and monsoon decreased highly in last 15 years. Temperature, drought occurrence, drought duration, storm, pest, irrigation cost and diseases were highly increased. Whereas crop production, flood occurrence, soil erosion have no change according to maximum farmers' perception.

\subsection{Changes in Cropping Pattern, Cropping Season and Crop Variety}

With the changes in climatic factors the cropping pattern and season also have found to be changed to cope with adverse climatic pressures. Farmers were asked about their past and present cropping pattern and season. They were asked about their cultivated crop variety also.

\subsubsection{Changes in Cropping Pattern}

Due to ingression of salinity, erratic rainfall and other climatic factors in dry season Rabi crops are mostly affected. So the motivation of cultivating Rabi crops decrease considerably. Beside late monsoon hampers B. Aus cultivation whereas high irrigation cost is needed. However innovation of modern high yielding varieties and modern technology slightly increase crop production and cropping intensity. The changes in cropping pattern is shown in the table 5.

Table 5. Cropping Pattern Changes in last 15 years.

\begin{tabular}{llllll}
\hline Cropping Pattern (15 Years ago) & & \multicolumn{3}{l}{ Cropping Pattern ( Present) } \\
\hline Rabi & Pre-Kharif & Kharif & Rabi & Pre-Kharif & Kharif \\
(Oct 15-Mar 15) & (Mar 15-July15) & (Jul 15-Oct 15) & (Oct 15-Mar 15) & (Mar15-Jul 15) & (Jul 15-Oct 15) \\
Fallow & Fallow & T. Aman(L) & Boro (HYV) & Fallow & T. Aman(L) \\
Chilli(L) & Fallow & T.Aman(L) & Fallow & T.Aus-(L/HYV)- & T. Aman (L/HYV) \\
Sweet Potato & Fallow & T. Aman(L) & Fallow & Fallow & T. Aman (L/HYV) \\
Fallow & Jute & Fallow & Sweet potato (L/HYV) & Fallow & T. Aman (L/HYV) \\
Fallow & B. Aus(L) & T.Aman (L) & Mungbean (HYV) & Fallow & T. Aman (L/HYV) \\
Sesame & Fallow & T.Aman (L) & & & \\
Fallow & T. Aus & Wheat & & & \\
Mungbean & Fallow & T.Aman (L) & & & \\
\hline
\end{tabular}

\subsubsection{Changes in Cropping Seasons and Area Coverage}

Crop calendar was made through FGD to determine changes in cropping season and amount of area and production comparing the earlier. The major crops and their cropping season are shown in the tables 6 and 7.

Table 6. Cropping Season in 15 Years Ago.

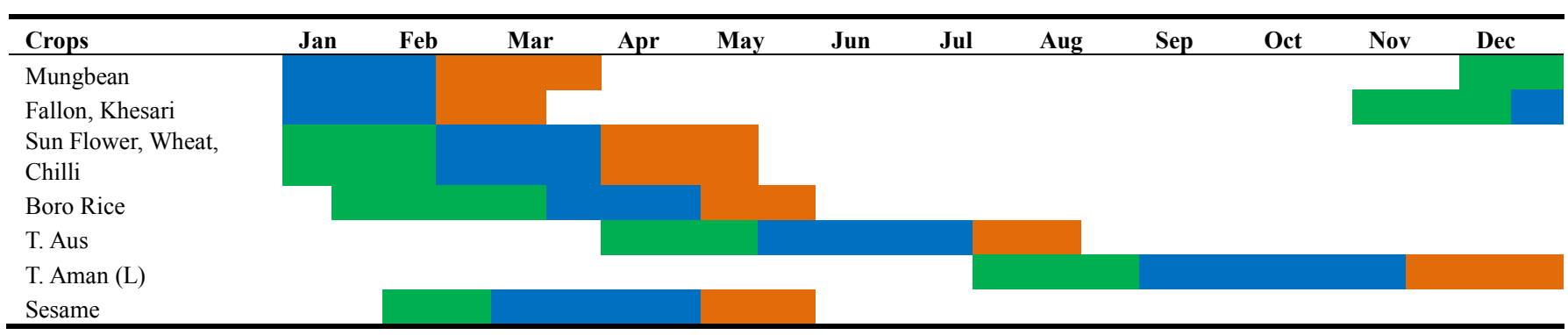


Table 7. Present Crop Calendar with Changes in Area Coverage Comparing Past.

\begin{tabular}{|c|c|c|c|c|c|c|c|c|c|}
\hline Crops & Variety & Jan & Feb & Mar & Apr & May & Jun & $\begin{array}{l}\text { Area Coverage } \\
\text { and Production } \\
\text { considering Past }\end{array}$ & Reasons \\
\hline Mungbean & & & & & & & & No comments & No comments \\
\hline Fallon, Khesari & & & & & & & & Decreased & Salinity affected \\
\hline $\begin{array}{l}\text { Sun Flower, } \\
\text { Wheat, Chilli }\end{array}$ & & & & & & & & Decreased & Salinity affected \\
\hline Boro Rice & $\begin{array}{l}\text { Brridhan } 47 \text {, Brridhan } 28 \text {, } \\
\text { Aloron, Rajkumar. }\end{array}$ & & & & & & & Uneven & $\begin{array}{l}\text { high yielding, High } \\
\text { profitable but hampered } \\
\text { by salinity }\end{array}$ \\
\hline T. Aus & $\begin{array}{l}\text { BR-2 (Mala IRRI), } \\
\text { Kaliburo }\end{array}$ & & & & & & & Decreased & $\begin{array}{l}\text { Late Rainfall, Irrigation } \\
\text { Cost and less profitable. }\end{array}$ \\
\hline T. Aman (L) & $\begin{array}{l}\text { Sadamota, Kachamota, } \\
\text { Rajashail }\end{array}$ & & & & & & & Decreased & $\begin{array}{l}\text { Low yield, Low } \\
\text { Profitable }\end{array}$ \\
\hline $\begin{array}{l}\text { T. Aman } \\
\text { (HYV) }\end{array}$ & $\begin{array}{l}\text { BR 11, BR 23, Brridhan 41, } \\
\text { Swarnamusuri }\end{array}$ & & & & & & & Increasing & $\begin{array}{l}\text { High yield, Early } \\
\text { Harvesting. }\end{array}$ \\
\hline
\end{tabular}

Table 7. Continue.

\begin{tabular}{|c|c|c|c|c|c|c|c|c|c|}
\hline Crops & Variety & Jul & Aug & Sep & Oct & Nov & Dec & $\begin{array}{l}\text { Area Coverage } \\
\text { and Production } \\
\text { considering Past }\end{array}$ & Reasons \\
\hline Mungbean & & & & & & & & No comments & No comments \\
\hline Fallon, Khesari & & & & & & & & Decreased & Salinity affected \\
\hline $\begin{array}{l}\text { Sun Flower, } \\
\text { Wheat, Chilli }\end{array}$ & & & & & & & & Decreased & Salinity affected \\
\hline Boro Rice & $\begin{array}{l}\text { Brridhan } 47 \text {, Brridhan } 28 \text {, } \\
\text { Aloron, Rajkumar. }\end{array}$ & & & & & & & Uneven & $\begin{array}{l}\text { high yielding, High } \\
\text { profitable but hampered } \\
\text { by salinity }\end{array}$ \\
\hline T. Aus & $\begin{array}{l}\text { BR-2 (Mala IRRI), } \\
\text { Kaliburo }\end{array}$ & & & & & & & Decreased & $\begin{array}{l}\text { Late Rainfall, Irrigation } \\
\text { Cost and less profitable }\end{array}$ \\
\hline T. Aman (L) & $\begin{array}{l}\text { Sadamota, Kachamota, } \\
\text { Rajashail }\end{array}$ & & & & & & & Decreased & $\begin{array}{l}\text { Low yield, Low } \\
\text { Profitable }\end{array}$ \\
\hline T. Aman (HYV) & $\begin{array}{l}\text { BR 11, BR 23, Brridhan 41, } \\
\text { Swarnamusuri }\end{array}$ & & & & & & & Increasing & $\begin{array}{l}\text { High yield, Early } \\
\text { Harvesting. }\end{array}$ \\
\hline
\end{tabular}

Table 7 shows that cultivation of Rabi crops, mungbean, sunflower, chilli, wheat decrease with time due to salinity problem in dry season. Area of cultivating T. Aus is also decreased in late monsoon due to high irrigation cost. Besides old local varieties are replaced by HYV varieties in Aman season. Cultivation of Boro has an uneven change because some area of Nilganj has little opportunities of fresh water irrigation by NGO initiatives and over there Boro is cultivated at medium to large scale but Chakamiya and Tiakhali are deprived of these opportunities due to salinity intrusion.

Beside from the field survey it is observed that earlier some crops such as jute, sugarcane and sesame were cultivated but at present these crops are not cultivated because of salinity and low profit.

Comparing the tables 6 and 7, it is observed that cropping seasons like sowing and harvesting time also has been changed. The reason behind is the late arrival of monsoon.

\subsubsection{Crop Variety Replacement}

It was observed that fifteen years ago, farmers used to cultivate local rice varieties like Kajalsail, Sadamota, Rajasail, Lalmota, Laxmibilash, Brindamoni, Shaitta, Shitabhog, Kutiagni, Jhingasail, Matichak etc and a few HYV rice such as BR11, BR22 but at present they mostly grow Vajan, BR11, BR23, BRRI dhan27, BRRI dhan30, BRRI dhan40, BRRI dhan41 etc. (table 8), which cover $60-99 \%$ land in T. Aman and about $60 \%$ land in T. Aus season. But due to shortage of fresh irrigated water during Boro season, BRRI dhan28 and BRRI dhan29 is cultivated in limited areas (about $10 \%$ land). Farmers are growing short duration and saline tolerant rice variety to escape salinity effect in later part of T. Aman season. Better saline resistant rice and other crop varieties are needed over there.

Table 8. Crop varieties are used comparing the last 15 years to present.

\begin{tabular}{|c|c|c|c|c|}
\hline Union & Previous crop varieties. & Presently cultivated varieties. & $\%$ area coverage. & Reasons for change. \\
\hline Tiakhali & Kajalsail, sadamota, Lalmota, & $\begin{array}{l}\text { BR11, BR23, Brridhan30, Brridhan41, } \\
\text { vajan. }\end{array}$ & 80 & $\begin{array}{l}\text { High yield, high profit } \\
\text { slightly saline resistant. }\end{array}$ \\
\hline Chakamiya & Laxibilash, Rajadail, ahaitta. & $\begin{array}{l}\text { BR11, BR23, Brridhan27, Brridhan28, } \\
\text { vajan. }\end{array}$ & 60 & $\begin{array}{l}\text { High yield, high profit } \\
\text { slightly saline resistant. }\end{array}$ \\
\hline Nilganj & $\begin{array}{l}\text { Kajalsail, Brindamont, Rangalakhi, } \\
\text { sadamota. }\end{array}$ & $\begin{array}{l}\text { Sadamota, BR11, BR23, Brridhan } 40 \text {, } \\
\text { Brridhan } 41 .\end{array}$ & 99 & $\begin{array}{l}\text { High yield, siltation in } \\
\text { depressed land facilitating } \\
\text { cultivation of BRRI }\end{array}$ \\
\hline
\end{tabular}




\section{Conclusions and Recommendations}

\subsection{Conclusions}

Global climate change is a growing threat to lives and livelihoods on earth, especially in developing countries. Bangladesh is one of the worst affected countries due to climate change. Crop agriculture of the coastal area is highly sensitive to climatic variations. The adverse impacts are evident including sea level rise, salinity intrusion, increasing frequency and intensity of tropical cyclone, storm surge, tidal surge and erratic rainfall over the study area. Different hazards have different extent of influence on cropping pattern. To minimize the loss of crop production it is very important to identify the major hazards with their time and extent of influence on cropping pattern. Salinity intrusion is one of the most significant hazards causing a huge yield reduction. Also cyclone, storm surge, erratic rainfall, tidal surge, pest attack and water logging have significant influence on crop yield reduction. Local farmers identified cyclone, salinity and tidal surge as major constrains to crop production. Cropping pattern and season are changing due to climatic variability. Cultivation of some crops has been increased whereas some other has been decreased. Cultivation of some crops such as jute, sesame, sugarcane are going to be extinct. For risk reduction in crop production some indigenous and innovative coping mechanisms can play significant role. Risk reduction options should be designed in priority and need basis considering the extent of hazards. Farmer's perception helps to diminish the gaps between development workers and farmers to identify their major problems. Also sectoral co-operation and co-ordination are required for the success.

\subsection{Recommendations}

From farmer's perception, questionnaire survey, focus group discussion and personal observations the following recommendations are identified;

I. Salinity is the major problem during dry Boro and Rabi season. So saline tolerant variety such as Binadhan 8 , Binadhan 10, Brridhan 55 (BARRI) may be introduced to the farmers and encouraging them to cultivate these types of variety.

II. Most of the farmer think cyclone and storm surge are major hindrance to crop production. Cyclone risk is high in post monsoon season (October-November) when $\mathrm{T}$. Aman rice are standing on field at mature stage (Field Survey). So dissemination of short duration rice may helpful and different structural mitigation measures should be taken as development initiatives.

III. Crop Calendar indicates cultivation of Rabi crops with wheat, potato, mungbean, khesari and Boro rice are decreasing due to salinity problem and lack of fresh water irrigation. So initiatives should be taken such as digging reservoir, canal, pond etc. to reserve and supply fresh water during dry season for irrigation.

\section{References}

[1] Agrawala, S, Ota, T, Ahmed, A.U, Smith, J, van Aalst, M (2003):Development and climate change in Bangladesh: focus on coastal flooding and the Sundarbans, OECD, Paris.

[2] Agriculture Extension Office, (2010): Kalapara, Patuakhali, Bangladesh.

[3] Ahmed, M. \& Suphachalasai, S, (2009): "Assessing the Costs of Climate Change and Adaptation in South Asia".

[4] Avhandling, A, (1981): "Peas , Ants byPreference? Socio- - Economic and Environmental Aspects of Rural Development in Tanzania".

[5] Bangladesh Bureau of Statistics, 2011:"Population and Housing Census, Socio-Economic and Demographic Report", National Series, Volume-4, Dhaka: Ministry of Planning.

[6] Banglapedia, (2003), National Encyclopedia of Bangladesh, Asiatic Society of Bangladesh, Dhaka, Bangladesh

[7] Bangladesh's National Adaptation Programme of Action (NAPA), 2010: an evaluation of the "Community-based Adaptation to Climate Change through Coastal Afforestation in Bangladesh" Project

[8] Barker, T., (2007): Climate Change 2007: An Assessment of the Intergovernmental Panel on Climate Change R. K. Pachauri $\&$ A. Reisinger, eds. Change, 446(November), pp.12

[9] Briefing, S., Published, S. \& Unnayan, B.Y, 2009: "Future Climate Change and Moisture Stress: Impact on Crop Agriculture in South-Western Bangladesh" 1(1), pp.1-8.

[10] BUET, (2008): "Field Investigation on the Impact of Cyclone SIDR".

[11] CEGIS, (2014): Center for Environmental and Geographic Information Services. Dhaka, Bangladesh.

[12] Haque, S.A., (2006): "Salinity Problems and Crop Poduction in Coastal Regions of Bangladesh", 38(5), pp.1359-1365.

[13] IPCC, A., 2007. Stern Review: The Economics of Climate Change.

[14] Islam, M. A. (2011): 'Climate Variations: Farming Systems".

[15] MOP. (2011): Sixth Five Year Plan of Bangladesh, General Economics. Dhaka.

[16] Rahman, A., (2008): "Climate change and its impact on health in Bangladesh", 12(1), pp.16-26.

[17] Yusuf, A.A. \& H. Francisco (2009), Climate Change Vulnerability Mapping for Southeast Asia (Singapore: Economy and Environment Program for Southeast Asia-EEPSEA) 